Makale Türü: Araştırma

\title{
Sağlık Yöneticilerinin Paternalist (Babacan) Liderlik Davranışlarının Çalışanların İş Doyumu Üzerine Etkisi
}

$* * *$

\section{The Effect of Paternalistic Leadership Behavior by Health Managers on Workers' Job Satisfaction}

\author{
Mustafa NAL \\ Marmara Üniversitesi Sağlık Bilimleri Enstitüsü, \\ Sağlık Yönetimi Doktora Öğrencisi, mustafanal@hotmail.com \\ Prof. Dr. Mehveş TARIM \\ Marmara Üniversitesi, Sağlık Bilimleri Enstitüsü, \\ Sağlık Yönetimi Ana Bilim Dalı, mehvestarim@yahoo.com
}

\begin{abstract}
Özet
$\mathrm{Bu}$ araştırma, sağlık yöneticilerinin göstermiş olduğu paternalist liderlik davranışlarının, sağlık çalışanlarının iş doyumu üzerindeki etkisini incelemek amacı ile yapılmıştır ve ilişkisel tarama modelinde betimsel bir çalışmadır. Araştırma, Kastamonu, Çankırı ve Karabük illerinde bulunan kamu ve özel hastanelerde, Temmuz 2016 - Mart 2017 tarihleri arasında yapılmıştır ve araştırmaya toplam 683 sağlık çalışanı katılmıştır. Araştırmaya katılanların \%67,9’u kadın (kamu 329, özel 135), \%32,1'i (kamu 152, özel 67) erkektir. Verilerin analizinde SPSS16 programı kullanılmıştır. Verilerin analizinde bağımsız örneklemler için t- testi, tek yönlü varyans analizi, pearson korelasyon analizi ve regresyon analizi kullanılmıştır. Yapılan korelasyon ve regresyon analizleri sonucuna göre paternalist liderliğin, iş doyumu üzerinde anlamlı ve yüksek düzeyde pozitif yönlü bir etkisi olduğu saptanmıştır $(\beta=530, \quad \mathrm{t}=16,322, \quad \mathrm{p}<0,01) . \mathrm{Bu}$ araştırma, sağlık yöneticilerinin paternalist liderlik davranışları arttıkça, sağlık çalışanlarında iş doyumunun da arttığını ortaya koymuştur.
\end{abstract}

Anahtar Kelimeler: Paternalist Liderlik, İş Doyumu, Sağlık Yönetimi.

Jel Sinıflandırması: J28, M12.

\begin{abstract}
Job satisfaction is one of the most important requirements so that health workers can be successful in their work. In order to get adequate and quality health services of patients, health workers must be satisfied with the their institution and their work.
\end{abstract}


This study aims to measure the job satisfaction of health workers, to identify factors affecting negatively and positively job satisfaction, to contribute to literature and health administrators. The study population consists 140 health workers working in a public hospital in Kastamonu. The study sampling consists 99 health workers agreed to participate to study. Data collection tool used in the study included a Demographic Information Form and Minnesota Job Satisfaction Scale. Intrinsic job satisfaction average score of health workers is 3,02 and in terms of intrinsic job satisfaction of health workers (achievement, recognition or appreciation, job responsibility) was determined to be satisfactory. Extrinsic satisfaction average score of workers is 2,63. Now that this rating is below 3 neutral score of scale, in terms of extrinsic job satisfaction of workers (agency policy and management, control method, relationships with managers and subordinates, work conditions, wages) was determined to be dissatisfied. It is believed to be useful taking corrective and remedial measures in this issue and review of factors of extrinsic job satisfaction such as agency policy and management, control method, relationships with managers and subordinates, work conditions, wages by managers.

Keywords: Paternalistic Leadership, Job Satisfaction, Health Management.

JEL Codes: J28, M12.

\section{GíRiş}

Sağl1k hizmetlerinin sunumunun her aşamasında insan vazgeçilmez bir unsurdur. Günümüzde teknoloji her ne kadar gelişmiş olsa da sağl1k sektöründe bu teknolojiyi kullanacak yine insandır. Bu sebeplerden ötürü, sağlık hizmetlerinin en önemli kaynă̆ını insan oluşturmaktadır. Sağlık işletmelerinin belirlenen amaç ve hedeflere ulaşabilmesi için yaptığı işten doyum alan, işi ile uyumlu, motivasyonu yüksek sağlık çalışanlarına ihtiyacı vardır. Organizasyon içinde bu ortamı sağlayacak ve organizasyonun belirlenen hedeflere ulaşmasını sağlayacak en önemli kişi ise yöneticilerdir. Yöneticilerin organizasyon içindeki tutum ve daranışlarının, en önemlisi liderlik davranışlarının, çalışanların motivasyonu ve iş tatmini üzerinde etkisi olacağı düşünülmektedir.

Organizasyonlar için yöneticilerin liderlik stilleri önemli bir faktördür. Lider olabilmek için takipçilerinin tamamına en iyi şekilde rehberlik edebilmek ve onları etkileme becerisine sahip olabilmek gerekir. Liderin kendisini takip edenleri etkileyebilmesi ve onlara rehberlik edebilmesi için kendi tecrübeleri ve yaşam tarzına bağlı bir liderlik stili benimsemesi gerekmektedir (Anwar, 2013, s.109). Liderlik üzerine yapılan çalışmalar incelendiğinde, farklı kültürlerde farklı liderlik davranışları olduğu 
görülmektedir (Türesin Tetik \& Köse, 2015, s.30). Asya ve Ortadoğu ülkelerinde gerçekleştirilen liderlik çalışmalarında batı ülkelerinden farklı olarak ortaya çıkan liderlik yaklaşımlardan birisinin de paternalist liderlik yaklaşımı olduğu görülmüştür (Cerit, 2013:841). Kültürel bir karakteristik gösteren paternalist liderlik, daha çok Pasifik Asya, Orta Doğu ve Latin Amerika toplumlarında gözlemlenmektedir (Aycan, 2006, s.445). Aycan ve Kanungo tarafindan on ülkede yapılan bir araştırmada, Türkiye'nin paternalizm ve topluluğa bağlılık açısından bu ülkeler içinde ikinci sırada olduğu saptanmıştır (Aycan vd., 2000, s.50). Paternalizmin, Türk toplumunda çok fazla görülmesinin sebebi olarak, Türk geleneklerine uygun olması gösterilebilir. Paternalizmin yaygın olarak görüldüğü toplumlar için genel bir değerlendirme yapıldığında bu toplumların ataerkil bir yapıya sahip oldukları söylenebilir (Yeşiltaş, 2013, s.53).

$\mathrm{Bu}$ araştırma, sağlık yöneticilerinin göstermiş olduğu paternalist liderlik davranışlarının, sağlık çalışanlarının iş doyumu üzerindeki etkisini incelemek amacı ile yapılmıştır ve ilişkisel tarama modelinde betimsel bir çalışmadır.

\section{PATERNALIST LIDERLIKK}

Lider, belirlenmiş amaçlar yönünde diğer insanları etkileyerek davranışa sevk eden kişidir. Başka bir ifade ile lider, bir grup insanın bireysel ve grup amaçlarını gerçekleştirmek için grup üyelerinin takip ettikleri, onun istek, emir ve talimatları doğrultusunda harekete geçtikleri kişiye denir (Koçel, 2011, s.569). Liderlik iktidarın bir yönüdür, ancak aynı zamanda bireysel ve hayati bir süreçtir (Burns, 1979, s.380). Liderlik, hedef belirleme ve belirlenen hedefe ulaşma doğrultusunda organize olmuş bir grubun faaliyetlerini etkileme süreci olarak tanımlanabilir (Stogdill, 1950, s.3). Bir başka tanıma göre, liderlik üyelerden birinin, diğer üyeleri güdüleme veya davranışlarını değiştirme gayretidir (Bass, 1960, s.96). Paternalist liderlik, liderin kendisini takip edenlere bir baba gibi davranması anlamını içermektedir. Paternalist lider, takipçilerinin işlerine yoğunlaşması için onların yardıma ihtiyacı olduğu her konuda (aile sorunları dahil) mümkün olan her çeşit yardımı yapar, onlar için endişelenir ve sonuç olarak çalışanlardan sadakat bekler (Anwar, 2013, s.109). Paternalist lider, astların 
özel yaşamlarına dâhil olur, onlara bir "baba" gibi yaklaşır ve onları koruyup kollar (Pellegrini ve Scandura, 2006, s.269). Paternalist lider, bir aile olarak algılanan organizasyondaki diğer bireylere ailenin bir üyesi olduklarını hissettirir. Bunu sağlamak için, yeni bir uygulamayı nasıl gerçekleştireceklerini, olması gerekenleri onlara anlatır, elde edilen sonuca göre onları zamanı geldiğinde ödüllendirir ya da ikaz eder. Çalışanlar, sorumluluk alma konusunda teşvik edilirler ve sorunlar istenilen şekilde çözülürse paternalist liderin mutlu olacağını düşünmektedirler. Çalışanlar, liderin istediği davranışı gösterir ve itaat ederler ise kendilerini lidere sevdirirler ve daha motive olmuş bir biçimde harekete geçerler (Keklik, 2012, s.80).

Paternalist liderlik, birçok ülkede tercih edilen bir liderlik tarzıdır. Toplulukçu ve yüksek güç mesafesi özelliği taşıyan birçok ülkede örneğin; Türkiye, Hindistan, Çin ve Meksika'da liderlik modeli olarak tercih edilmektedir (Salminen-Karlsson, 2015). Paternalist liderlik, güçlü disiplin ve otoriteyi, babacan yardımseverlik ve ahlaki dürüstlük ile birleştiren bir liderlik tarzı olarak ifade edilmektedir (Türesin Tetik ve Köse, 2015). Paternalist kültürde, ebeveynler ve yaşlı aile üyeleri, genç aile üyelerinin refahını korumak, onların kararlarına etki etmek, onların davranışlarını disipline etmek ve onlar adına davranışta bulunmak gibi fonksiyonlara sahiptir (Mustafa ve Lines, 2012).

Araştırmacılar, paternalist liderliği kültürel açıdan olumlu ve olumsuz olarak farklı şekillerde yorumlamaktadır. Örneğin batılı araştırmacılar paternalist liderliği olumsuz olarak değerlendirmekte iken, paternalist liderliğin yaygın olduğu toplumlardaki araştırmacılar ise paternalist liderliği olumlu olarak değerlendirmektedirler (Salminen-Karlsson, 2015, s.411). Paternalist liderin astlarının yaşamlarına dâhil olması; doğu kültüründe, yani yüksek güç mesafesine sahip bir toplumda, liderin kaygı ve koruma rolünün bir parçası olarak algılanabilir, ancak batı kültüründe bireyci, yani düşük güç mesafesine sahip bir toplumda, mahremiyet ihlali olarak algılanmaktadır (Jackson, 2016, s.4).

\section{3. İ̧̧ DOYUMU}


İş doyumu, örgütsel davranış açısından kişinin işine karşı oluşturduğu en önemli tutumlar arasında yer almaktadır (Özkalp, 2013, s.71 ). Organizasyonlarda söz konusu olan verimlilik ve etkililik olduğunda, iş doyumu en önemli faktörlerden biri olarak karşımıza çıkmaktadır (Aziri, 2011, s.78). İş doyumu; işgörenlerin iş ortamı, işin doğası, ücret, promosyonlar, kontrol ve çalışma ilişkilerini içine alan çok yönlü bir kavramdır (Papaconstantinou ve Triantafyllou, 2015, s.165). Çalışanın işine karşı geliştirdiği tutum olumlu ise çalışanın tatmin olma düzeyinin yüksek olduğu gözlemlenmekte iken, bireyin işine karşı tutumu olumsuz olduğu durumda ise tatmin olma düzeyinin düşük olduğu gözlemlenmektedir (Özkalp, 2013, s.71). Çalışanlarının iş doyumunu sağlayan işletmelerin, personel bulmakta problem yaşamadığ 1 , çalışanların devamlılık gösterdiği ve işgücü devir hızlarının düşük olduğu görülmektedir. Bu duruma karşın, çalışanların iş doyumunu sağlayamayan işletmelerde ise personel bulmakta güçlük çektiği ve işgücü devir hızının yüksek olduğu bilinmektedir (Sur ve Palteki, 2013, s.154). Yaptığı işten doyum sağlayan kişinin, kapasitesinin, performansının ve buna ek olarak ortaya konulan işin niteliğinin de yükselmesi beklenmektedir (Bakker ve Demerouti, 2007, s.313).

İş doyumu, kişisel bir algıyı ifade ettiği için örgütsel süreçlerin yanında bireysel faktörlerden de etkilenmektedir (Tanrıverdi ve Paşaoğlu, 2014, s.278). Lawler ve Porter'ın, iş doyumu ile ilgili yaptığı ilk çalışmalar incelendiğinde, iş doyumunu yaş, cinsiyet, eğitim, meslek ve gelir durumunun etkilediği görülmektedir (Izvercian ve vd., 2016, s.86). İş doyumunu etkileyen faktörler, bireysel ve örgütsel faktörler olmak üzere iki grupta ele alınabilir. Bireysel faktörler; yaş, cinsiyet, eğitim durumu, mesleki statü, mesleki kıdem, karakter, zekâ, hizmet süresi, medeni durum ve bunlara benzer etmenlerden oluşmaktadır. Örgütsel faktörler; işin niteliği, yönetim ve kontrol biçimi, örgüt içi iletişim, gelişme ve yükselme koşulları, rekabet, örgüt iklimi, çalışma şartları, sosyal görünüm ve benzeri faktörlerden oluşmaktadır (Tengilimoğlu, 2005, s.28). Liderlik tarzlarının iş doyumu üzerine etkisi incelendiğinde ise demokratik liderlik, tam serbesti tanıyan liderlik gibi bazı liderlik tarzlarının iş doyumunu arttırmakta iken, bazı liderlik tarzlarının (otokratik) ise iş doyumunu azalttığı görülmektedir (Kibbe, 2015, s.53-54). 


\section{GEREÇ VE YÖNTEM}

Araştırmanın evrenini Türkiye'deki kamu hastaneleri ve özel hastaneler oluşturmaktadır. Bütün hastaneleri temsil ettiği kabul edilen, araştırmacının kolay ulaşabileceği Kastamonu, Çankırı ve Karabük illerinde bulunan iki kamu ve iki özel hastane örneklem olarak seçilmiştir.2016 - Mart 2017 tarihleri arasında araştırmaya katılmayı kabul eden 706 sağlık personeline anket uygulanmıştır. Eksik veya yanlış doldurulan 23 anket araştırmadan çıkarılmıştır ve toplam 683 anket değerlendirmeye alınmıştır.

$\mathrm{Bu}$ araştırmada çalışanlarının sosyodemografik özelliklerine ait verileri toplamak için "Kişisel Bilgi Formu" kullanılmıştır. Paternalist liderlik algısını ölçmek için Pellegrini ve Scandura (2006) tarafından geliştirilen ve 13 ifadeden oluşan Paternalist Liderlik Ölçeğiden yararlanılmıştır. Beşli Likert türünde olan ölçekte; "1=kesinlikle katılmıyorum", "2=katılmıyorum", "3=kısmen kat1lyorum", 4=katılıyorum", " $5=$ kesinlikle kat1lyorum", şeklinde ifadeler yer almaktadır. Ölçek maddelerinden elde edilen puanların ortalaması paternalist liderlik puanını oluşturmaktadır. Ölçek ortalamasının 3'ten küçük olması düşük paternalist liderlik algısı, ortalamanın 3'ün üstünde olması yüksek paternlist liderlik algıs1, ortalamanın 3'e olması ise orta düzeyde paternalist liderlik algısı olarak değerlendirilmiştir.

İş doyumunu ölçmek için, Weiss, Davis England ve Lofquist (1967) tarafından geliştirilen ve Oran (1989) tarafindan Türkçeye uyarlanan Minnessota Doyum Ölçeği'nden yararlanılmıştır. Ölçek içsel, dışsal ve genel doyum faktörlerini ölçmeyi sağlayan, "1=hiç memnun değilim", 5=çok memnunum" arasındaki ifadeleri kapsayan beşli likert tipi bir ölçektir. İş doyumu ölçeğinde yer alan tüm maddelerden elde edilen puanların ortalaması (20'ye bölünmesi ile) genel doyum puanını oluşturur. İçsel doyum puanı (1, $2,3,4,7,8,9,10,11,15,16,20)$ içsel doyum ile ilgili maddelerin ortalamasının 12' ye bölünmesi ile elde edilmektedir. Dışsal doyum puanı; kurum politikası ve yönetimi, denetim şekli, yönetici ve astlarla ilişkiler, çalışma koşulları, ücret gibi işin çevresine ait öğelerden oluşan maddeleri kapsamaktadır. Ölçekte dışsal doyum ile ilgili yer alan maddelerden $(5,6,12$, $13,14,17,18,19)$ elde edilen puanların toplamının 8'e bölünmesi ile dışsal doyum puanı hesaplanmaktadır. Ölçek puan ortalamasının 3 olması iş doyumunun nötr olduğunu ifade etmektedir. Ölçeğin ortalama puanının 3'ün 
altında olması düşük iş doyumu, 5'e yakın olması ise yüksek iş doyumu olarak değerlendirilmektedir.

\subsection{Araştırmanın Modeli ve Hipotezleri}

Araştırmanın modeli şekil 1'de gösterilmiştir.

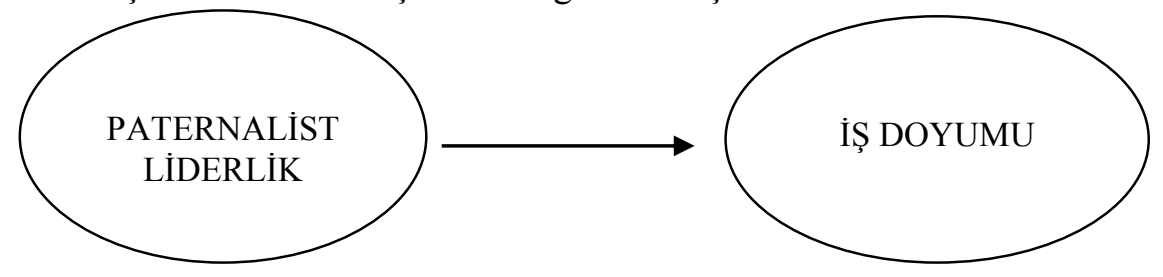

Şekil 1. Araştırmanın modeli.

Araştırmanın amacına yönelik hazırlanan hipotezler aşağıda verilmiştir.

$\mathrm{H}_{1}$ : Paternalist liderlik davranışları ile genel iş doyumu arasında istatistiksel açıdan anlamlı bir ilişki vardır.

$\mathrm{H}_{2}$ : Paternalist liderlik davranışları ile içsel doyum arasında istatistiksel açıdan anlamlı bir ilişki vardır.

$\mathrm{H}_{3}$ : Paternalist liderlik davranışları ile dışsal doyum arasında istatistiksel açıdan anlamlı bir ilişki vardır.

\subsection{Paternalist Liderlik ve İş Doyumu Ölçeklerinin Güvenilirlik ve Geçerlilik Analizi}

Araştırmada kullanılan ölçeklerin güvenirliğini ölçmek için Cronbach Alpha değerleri ölçülmüştür. Paternalist liderlik ölçeğinin Cronbach Alpha değeri 0,890 olarak tespit edilmiştir. Bu sonuç paternalist liderlik ölçeğinin yüksek düzeyde güvenilir olduğunu göstermektedir. İş doyumu ölçeği Cronbach Alpha değeri 0,910 olarak bulunmuştur. İş doyumu ölçeğinin alt boyutlarını oluşturan; içsel doyum boyutu için Cronbach Alpha değeri 0,887 olarak saptanmıştır, dışsal doyum boyutu için ise Cronbach Alpha değeri 0,861 olarak saptanmıştır. Bu sonuçlara göre iş doyumu ölçeğinin yüksek düzeyde güvenilir olduğu tespit edilmiştir.

Araştırmada kullanılan iş doyumu ölçeğinin yapı geçerliliğini ölçmek için ölçekte bulanan 20 madde seçilerek, Principal Components tekniği ile Promax döndürme yöntemi ve iki boyutlu (faktörlü) sınıflandırma seçilerek 
yapılmıştır. Yapılan analiz sonucunda $\mathrm{p}=0,000, \mathrm{KMO}$ değeri 0,924 olarak bulunmuştur ve iş doyumu ölçeğinin faktör analizi yapılmasına uygun olduğu saptanmıştır. Ayrıca ölçek maddeleri ile ilgili faktör dağılımının, orijinal ölçek ile aynı boyutlarda olduğu tespit edilmiştir. Paternalist liderlik ölçeğinin yapı geçerliliğini ölçmek için faktör analizi yapılmıştır ve verilerin analizinde Kaiser-Meyer-Olkin (KMO) ve Barlett testi uygulanmıştır. Yapılan analiz sonucunda ölçeğin 6 . maddeye yeterli düzeyde yüklenme olmadığı için bu ifade ölçekten çıkarılarak, diğer 12 maddenin analizi tekrarlanmıştır. Tekrarlanan analiz sonucunda Kaiser-Meyer-Olkin (KMO) ve Barlett testi incelenmiştir ve KMO değeri 0,954 ve $p=0,000$ olarak anlamlı bulunmuştur. $\mathrm{Bu}$ sonuçlara göre ölçeğin faktör analizi için uygun olduğu tespit edilmiştir. Faktör analizi sonucunda Paternalist Liderlik Ölçeği'nin orijinal ölçekte olduğu gibi tek faktörden oluştuğu görülmüştür.

\subsection{Kullanılan İstatistiksel Yöntemler}

Araştırmada elde edilen verilerin analizinde SPSS 16 programı kullanılmıştır. Normal dağılım gösteren bağımsız iki grubun karşılaştırılmasında Bağımsız T testi, ikinin üzerindeki bağımsız grupların karşılaştırılmasında Tek Yönlü Anova analizi uygulanmıştır. Normal dağılım özelliği göstermeyen üç veya daha çok bağımsız grubun karşılaştırılmasında Kruskal Wallis analizi yapılmıştır. Ölçümsel değişkenler arasındaki ilişkinin ortaya konması için ise Korelasyon Analizi ve Basit Doğrusal Regresyon Analizi yapılmıştır.

\section{BULGULAR}

Araştırmada elde edilen verilerin analiz sonuçlarına ait bulgular aşağıda alt başlıklar halinde verilmiştir.

\subsection{Demografik Özelliklere Ait Bulgular}

Sağlık çalışanlarına ait demografik bulgular Tablo 1' de gösterilmiştir.

Tablo 1. Sağlık çalışanlarına ait demografik bulgular

\begin{tabular}{llcccccc}
\hline \multirow{2}{*}{ Demografik Özellikler } & \multicolumn{2}{c}{ Kamu } & \multicolumn{2}{c}{ Özel } & \multicolumn{2}{c}{ Toplam } \\
& & $\mathrm{n}$ & $\%$ & $\mathrm{n}$ & $\%$ & $\mathrm{n}$ & $\%$ \\
\hline \multirow{2}{*}{ Cinsiyet } & Kadın & 329 & 68,4 & 135 & 68,8 & 464 & 67,9 \\
& Erkek & 152 & 31,6 & 67 & 33,2 & 219 & 32,1
\end{tabular}




\begin{tabular}{|c|c|c|c|c|c|c|c|}
\hline & Toplam & 481 & 100 & 202 & 100 & 683 & 100 \\
\hline \multirow{5}{*}{ Yaş } & $16-25$ yaş & 79 & 16,4 & 85 & 42,1 & 164 & 24,0 \\
\hline & $26-35$ yaş & 164 & 34,1 & 85 & 42,1 & 249 & 36,5 \\
\hline & $36-50$ yaş & 218 & 45,3 & 27 & 13,4 & 245 & 35,9 \\
\hline & 51 ve üstü yaş & 20 & 4,2 & 5 & 2,5 & 25 & 3,6 \\
\hline & Toplam & 481 & 100 & 202 & 100 & 683 & 100 \\
\hline \multirow{4}{*}{$\begin{array}{l}\text { Eğitim } \\
\text { Durumu }\end{array}$} & Lise & 98 & 20,4 & 125 & 61,9 & 223 & 32,7 \\
\hline & Üniversite & 335 & 69,6 & 59 & 29,2 & 394 & 57,7 \\
\hline & Lisansüstü & 48 & 10,0 & 18 & 8,9 & 66 & 9,6 \\
\hline & Toplam & 481 & 100 & 202 & 100 & 683 & 100 \\
\hline \multirow{4}{*}{$\begin{array}{l}\text { Medeni } \\
\text { Durum }\end{array}$} & Bekâr & 137 & 28,5 & 88 & 43,6 & 225 & 32,9 \\
\hline & Evli & 338 & 70,3 & 111 & 55,0 & 449 & 65,7 \\
\hline & Dul & 6 & 1,3 & 3 & 1,5 & 9 & 1,3 \\
\hline & Toplam & 481 & 100 & 202 & 100 & 683 & 100 \\
\hline \multirow{11}{*}{ Meslek } & Hekim & 29 & 6,0 & 25 & 12,4 & 54 & 7,9 \\
\hline & Hemşire & 240 & 49,9 & 81 & 40,1 & 321 & 47,0 \\
\hline & $\begin{array}{l}\text { Sağlık } \\
\text { Memuru }\end{array}$ & 32 & 6,7 & 8 & 4,0 & 40 & 5,8 \\
\hline & Ebe & 46 & 9,6 & 1 & 0,5 & 47 & 6,9 \\
\hline & Tibbi Sekreter & 28 & 5,8 & 24 & 11,9 & 52 & 7,6 \\
\hline & Laborant & 23 & 4,8 & 7 & 3,5 & 30 & 4,4 \\
\hline & $\begin{array}{l}\text { Acil Tip } \\
\text { Teknikeri }\end{array}$ & 27 & 5,6 & 37 & 18,3 & 64 & 9,4 \\
\hline & $\begin{array}{l}\text { Radyoloji } \\
\text { Teknikeri }\end{array}$ & 26 & 5,4 & 8 & 4,0 & 34 & 5,0 \\
\hline & $\begin{array}{l}\text { Anestezi } \\
\text { Teknikeri }\end{array}$ & 13 & 2,7 & 6 & 3,0 & 19 & 2,8 \\
\hline & $\begin{array}{l}\text { Diğer Sağlık } \\
\text { Personeli }\end{array}$ & 17 & 3,5 & 5 & 2,5 & 22 & 3,2 \\
\hline & Toplam & 481 & 100 & 202 & 100 & 683 & 100 \\
\hline \multirow{5}{*}{$\begin{array}{c}\mathrm{Bu} \\
\text { kurumdaki } \\
\text { çalışma } \\
\text { süresi }\end{array}$} & $0-1$ y1l & 52 & 10,8 & 43 & 21,3 & 95 & 13,9 \\
\hline & 2-4 y1l & 162 & 33,7 & 74 & 36,6 & 236 & 34,6 \\
\hline & $5-10$ y1l & 163 & 33,9 & 68 & 33,7 & 231 & 33,8 \\
\hline & 11 y1l ve üstü & 104 & 21,6 & 17 & 8,4 & 121 & 17,7 \\
\hline & Toplam & 481 & 100 & 202 & 100 & 683 & 100 \\
\hline \multirow{5}{*}{$\begin{array}{l}\text { Toplam } \\
\text { çalışma } \\
\text { süresi }\end{array}$} & $0-1$ y1l & 23 & 4,8 & 38 & 18,8 & 61 & 8,9 \\
\hline & $2-4$ y1l & 102 & 21,2 & 67 & 33,2 & 169 & 24,8 \\
\hline & $5-10$ y1l & 148 & 30,8 & 64 & 31,7 & 212 & 31,0 \\
\hline & 11 yıl ve üstü & 208 & 43,2 & 33 & 16,3 & 241 & 35,3 \\
\hline & Toplam & 481 & 100 & 202 & 100 & 683 & 100 \\
\hline \multirow{4}{*}{$\begin{array}{c}\text { Çalışma } \\
\text { vardiyası }\end{array}$} & Gece & 3 & 0,6 & 8 & 4,0 & 11 & 1,6 \\
\hline & Gündüz & 163 & 33,9 & 79 & 39,1 & 242 & 35,4 \\
\hline & $\begin{array}{l}\text { Gece ve } \\
\text { Gündüz }\end{array}$ & 315 & 65,5 & 115 & 56,9 & 430 & 63,0 \\
\hline & Toplam & 481 & 100 & 202 & 100 & 683 & 100 \\
\hline
\end{tabular}




\begin{tabular}{|c|c|c|c|c|c|c|c|}
\hline \multirow{5}{*}{$\begin{array}{c}\text { Aylik } \\
\text { ortalama } \\
\text { nöbet } \\
\text { tutma } \\
\text { durumu }\end{array}$} & $\begin{array}{l}\text { Nöbet } \\
\text { tutmayan }\end{array}$ & 148 & 30,8 & 77 & 38,1 & 225 & 32,9 \\
\hline & 1-4 nöbet & 72 & 15,0 & 23 & 11,4 & 95 & 13,9 \\
\hline & 5-9 nöbet & 237 & 49,3 & 34 & 16,8 & 271 & 39,7 \\
\hline & $\begin{array}{l}10 \text { ve üzeri } \\
\text { nöbet }\end{array}$ & 24 & 5,0 & 68 & 33,7 & 92 & 13,5 \\
\hline & Toplam & 481 & 100 & 202 & 100 & 683 & 100 \\
\hline \multirow{5}{*}{$\begin{array}{l}\text { Aylık } \\
\text { ortalama } \\
\text { çalışma } \\
\text { süresi }\end{array}$} & $130-159$ saat & 12 & 2,5 & 1 & 0,5 & 13 & 1,9 \\
\hline & $160-189$ saat & 265 & 55,1 & 45 & 22,3 & 310 & 45,4 \\
\hline & 190-219 saat & 117 & 24,3 & 74 & 36,6 & 191 & 28,0 \\
\hline & $\begin{array}{l}220 \text { ve üstü } \\
\text { saat }\end{array}$ & 87 & 18,1 & 82 & 40,6 & 169 & 24,7 \\
\hline & Toplam & 481 & 100 & 202 & 100 & 683 & 100 \\
\hline \multirow{4}{*}{$\begin{array}{l}\text { İstihdam } \\
\text { türü }\end{array}$} & Kadrolu & 448 & 93,1 & 0 & 0,0 & 448 & $\overline{65,6}$ \\
\hline & $\begin{array}{l}\text { Sözleşmeli } \\
(4 / b)\end{array}$ & 16 & 3,3 & 0 & 0,0 & 16 & 2,3 \\
\hline & Özel şirket & 17 & 3,5 & 202 & 100 & 219 & 32,1 \\
\hline & Toplam & 481 & 100 & 202 & 100 & 683 & 100 \\
\hline
\end{tabular}

Araştırmaya katılanların \%67,9'u kadın, \%32,1'i erkektir. Katılımcıların \%24'ü16-25 yaş aralığındadır, \%36,5'i 26-35 yaş aralığındadır, \%35,9'u36-50 yaş aralığındadır ve \%3,6's151 yaş ve üzerindedir. Katılımcıların \%32,7'si lise mezunu, \%57,7'si üniversite (önlisans ve lisans) mezunu, \%9,6'sılisansüstü eğitim mezunudur. Araştırmaya katılanların medeni durumları incelendiğinde \%32,9'unun bekâr, \%65,7'sininevli, \%1,3'ünün dul olduğu saptanmıştır. Katılımcıların meslek gruplarına göre dağılımı incelendiğinde; \%7,9'unun hekim, \%47'sinin hemşire, \%5,8'inin sağlık memuru, \%6,9'unun ebe, \%7,6'sının tıbbi sekreter, \%4,4'ünün laborant, \%9,4'ünün acil tıp teknikeri, \%5'inin radyoloji teknikeri, \%2,8'inin anestezi teknikeri, \%3,2'sinin diğer sağlık personeli olduğu tespit edilmiştir.

Araştırmaya katılanların halen çalıştıkları kurumdaki çalışma süreleri incelendiğinde, \% 13,9'unun 0-1 y11, \%34,6'sının 2-4 y11, \%33,8'inin 5-10 y11, $\% 17,7$ 'sinin 11 yıl ve daha fazla çalıştıkları saptanmıştır. Katılımcıların toplam çalışma süreleri incelendiğinde, \%8,9'unun 0-1 y11, \%24,8'inin 2-4 yıl, \%31'inin 5-10 yı1, \%35,3'ünün ise 11 yıl ve daha çok süredir çalıştıkları belirlenmiştir. Araştırmaya katılan sağlık personellerinin çalışma vardiyaları incelendiğinde, \%1,6'sının sadece gece, \%35,4'ünün sadece gündüz, \%63'ünün hem gece hem gündüz vardiyalarında çalıştıkları tespit edilmiştir. Katılımcıların aylık nöbet tutma durumları incelendiğinde, \%32,9'unun hiç 
nöbet tutmadığ $1, \% 13,9$ 'ununa ylık1-4 nöbet tuttuğu, \%39,7'sinin aylık 5-9 nöbet tuttuğu, \%13,5'inin aylık 10 ve daha fazla nöbet tuttuğu belirlenmiştir. Katılımcıların aylık ortalama çalışma süreleri incelendiğinde, \%1,9'unun aylık 130-159 saat, \%45,4'ünün aylık 160-189 saat, \% 28'inin aylık 190-219 saat, \%24,7'sinin aylık 220 ve saat daha fazla saat çalıştı̆̆ saptanmıştır. Çalışanların istihdam türlerine göre çalışma şekilleri incelendiğinde; \%65,6'sının (kamu 448) kadrolu (657 sayılı kanunun 4/a maddesine göre), \%2,3'ünün (kamu 16) sözleşmeli (657 sayılı kanunun 4/b maddesine göre), 32,1'inin (kamu 17, özel 202) özel şirket personeli olarak çalıştıkları tespit edilmiştir.

\subsection{Sağlık Çalışanlarının Paternalist Liderlik ve İş Doyumları ile İlgili Bulgular}

Sağlık çalışanlarının, paternalist liderlik algı düzeylerine ait puan ortalamaları Tablo 2'de gösterilmiştir. Kamu hastanelerinde çalı̧̧anların

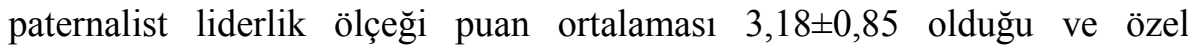

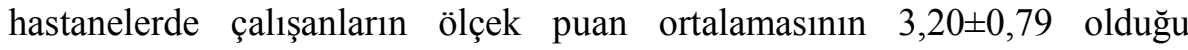
saptanmıştır. Her iki sektörde paternalist liderlik algısının orta düzeyde olduğu saptanmıştır.

Tablo 2.Sağlık Çalışanlarının Paternalist Liderlik Algı Düzeyleri

\begin{tabular}{lrrrr}
\hline & \multicolumn{2}{c}{ Kamu $(\mathrm{n}=481)$} & \multicolumn{2}{c}{ Özel $(\mathrm{n}=202)$} \\
\cline { 2 - 5 } & Ortalama & Standart sapma & Ortalama & Standart sapma \\
\hline $\begin{array}{l}\text { Paternalist } \\
\text { liderlik }\end{array}$ & 3,18 & 0,85 & 3,20 & 0,79 \\
\hline
\end{tabular}

Araştırmaya katılan sağlık çalışanlarının iş doyumu ölçek puan ortalamalarına ait bulgular Tablo 3'te verilmiştir. Sağlık çalışanlarının içsel doyum puan ortalamalarının kamu hastanelerinde 3,24 ve özel hastanelerde 3,36 olduğu, dişsal doyum puan ortalamalarının kamu hastanelerinde çalışanların 3,06 olduğu, özel hastanelerde çalışanlarının 3,03 olduğu saptanmıştır. Genel iş doyumu puan ortalamasının, kamu hastanelerinde çalışanların 3,17 olduğu, özel hastanelerde çalışanların puan ortalamasının 
3,23 olduğu tespit edilmiştir. Her iki sektörde sağlık çalışanlarının iş doyumlarının orta düzeyde olduğu saptanmıştır.

Tablo 3. Sağlık Çalışanlarının İş Doyumu Düzeyleri

\begin{tabular}{lrrrr}
\hline & \multicolumn{2}{c}{ Kamu $(\mathrm{n}=481)$} & \multicolumn{2}{c}{ Özel $(\mathrm{n}=202)$} \\
\cline { 2 - 5 } Boyutlar & Ortalama & Standart sapma & Ortalama & Standart sapma \\
\hline İçsel Doyum & 3,24 & 0,82 & 3,36 & 0,80 \\
Dişsal doyum & 3,06 & 0,84 & 3,03 & 0,89 \\
$\begin{array}{l}\text { Genel iş } \\
\text { doyumu }\end{array}$ & 3,17 & 0,70 & 3,23 & 0,79 \\
\hline
\end{tabular}

\subsection{Araştımaya Katılan Sağlık Çalışanlarının Demografik Özellikleri İle İş Doyumu ve Paternalist Liderlik Algılarının Karşılaştırılması}

Araştırmaya katılan sağlık çalışanlarının, İş Doyumu ve Paternalist Liderlik puan ortalamaları ile cinsiyet arasında anlamlı bir fark olup olmadığını incelemek için, Bağımsız örneklem T testi uygulanmıştır. Sağlık çalışanlarının, cinsiyete göre iş doyumu puan ortalamaları arasındaki farkın istatistiksel açıdan anlamlı olmadığı bulunmuştur $(\mathrm{p}>0,05)$. Sağlık çalışanlarının, cinsiyete göre paternalist liderlik puan ortalamaları arasındaki farkın istatistiksel açıdan anlamlı olmadığı bulunmuştur ( $\mathrm{p}>0,05)$.

Sağlık çalışanlarının, eğitim durumlarına göre iş doyumu ve paternalist liderlik puan ortalamaları arasındaki farkın anlamlı olup olmadığını incelemek için Anova (Tek yönlü varyans) analizi yapılmıştır. Katılımcıların eğitim durumlarına göre iş doyumu puan ortalamaları arasındaki farkın istatistiksel açıdan anlamlı olduğu saptanmıştır $(\mathrm{p}<0,05)$. Yapılan Post Hoc Tukey testi sonucunda, lisansüstü eğitim mezunlarının iş doyumu puan ortalarının $(3,40 \pm 0,70)$, üniversite mezunlarının iş doyumu puan ortalarından $(3,17 \pm 0,69)$ yüksek olduğu saptanmıştır. Sağlık çalışanlarının eğitim durumlarına göre içsel doyum puan ortalamaları arasındaki farkın istatistiksel açıdan anlamlı olduğu saptanmıştır $(\mathrm{p}<0,05)$. Yapılan Post Hoc Tukey testi sonucuna göre, lisansüstü eğitim mezunlarının içsel doyum puan ortalamalarının $(3,57 \pm 0,79)$, üniversite mezunlarının içsel doyumu puan ortalamalarından $(3,24 \pm 0,80)$ ve lise mezunlarının içsel doyumu puan 
ortalamalarından $(3,26 \pm 0,84)$ yüksek olduğu saptanmıştır. Sağlık çalışanlarının eğitim durumlarına göre paternalist liderlik puan ortalamaları arasındaki farkın istatistiksel açıdan anlamlı olmadığı saptanmıştır $(p>0,05)$.

Araştırmaya katılan sağlık personellerinin, çalışma vardiyası durumlarına göre iş doyumu, örgütsel adalet algısı ve paternalist liderlik puan ortalamaları arasında anlamlı bir fark olup olmadığını incelemek için, Kruskal Wallis testi uygulanmıştır. Katılımcıların çalışma vardiyası durumlarına göre iş doyumu puan ortalamaları arasındaki farkın istatistiksel açıdan anlamlı olduğu tespit edilmiştir $(\mathrm{p}<0,05)$. Yapılan Post Hoc Tamhane's testi sonucuna göre, gündüz vardiyasında çalışanların iş doyumu puan ortalamalarının $(3,20 \pm 0,73)$, gece vardiyasında çalışanların iş doyumu puan ortalamalarından $(2,60 \pm 0,47)$ yüksek olduğu saptanmıştır. Ayrıca hem gece hem de gündüz vardiyasında çalışanların iş doyumu puan ortalamalarının $(3,16 \pm 0,72)$, gece vardiyasında çalışanların iş doyumu puan ortalamalarından $(2,60 \pm 0,47)$ yüksek olduğu tespit edilmiştir.

Katılımcıların çalışma vardiyası durumlarına göre içsel doyum puan ortalamaları arasındaki farkın istatistiksel yönden anlamlı olduğu tespit edilmiştir $(\mathrm{p}<0,05)$. Yapılan Post HocTamhane's testi sonucuna göre, gündüz vardiyasında çalışanların içsel doyum puan ortalamalarının $(3,32 \pm 0,84)$, gece vardiyasında çalışanların içsel doyum puan ortalamalarından $(2,57 \pm 0,58)$ yüksek olduğu saptanmıştır. Ayrıca hem gece hemde gündüz vardiyasında çalışanların içsel doyum puan ortalamalarının $(3,27 \pm 0,80)$, gece vardiyasında çalışanların iş doyumu puan ortalamalarından $(2,57 \pm 0,58)$ yüksek olduğu tespit edilmiştir.

Katılımcıların çalışma vardiyası durumlarına göre paternalist liderlik puan ortalamaları arasındaki farkın istatistiksel açıdan anlamlı olduğu tespit edilmiştir $(\mathrm{p}<0,05)$. Yapılan Post Hoc Tamhane's testi sonucuna göre, hem gece hem de gündüz vardiyasında çalışanların paternalist liderlik puan ortalamalarının $(3,21 \pm 0,83)$, gece vardiyasında çalışanların paternalist liderlik puan ortalamalarından $(2,6 \pm 0,66)$ yüksek olduğu tespit edilmiştir.

Tablo 4. Sağlık Çalışanlarının Meslek Gruplarına Göre İş Doyumu ve Alt boyutlarına İlişkin Kruskal Wallis Testi Bulguları 


\begin{tabular}{|c|c|c|c|c|c|c|c|}
\hline & Meslek & $\mathrm{n}$ & Ort. & SS & $\begin{array}{l}\text { Chi- } \\
\text { square }\end{array}$ & $\mathrm{p}$ & Fark \\
\hline \multirow{11}{*}{$\begin{array}{l}\text { İş } \\
\text { doyumu }\end{array}$} & A-Hemşire & 321 & 3,18 & 0,69 & \multirow{11}{*}{32,154} & \multirow{11}{*}{0,000} & \multirow{11}{*}{$\begin{array}{l}\text { A-B } \\
\text { B-D } \\
\text { B-E } \\
\text { B-H }\end{array}$} \\
\hline & B-Hekim & 54 & 3,57 & 0,70 & & & \\
\hline & $\begin{array}{l}\text { C-Sağlık } \\
\text { memuru }\end{array}$ & 40 & 3,25 & 0,75 & & & \\
\hline & D-Ebe & 47 & 2,90 & 0,76 & & & \\
\hline & $\begin{array}{l}\text { E-Tibbi } \\
\text { sekreter }\end{array}$ & 52 & 3,10 & 0,63 & & & \\
\hline & F-Laborant & 30 & 3,25 & 0,65 & & & \\
\hline & G-Acil tıp & 64 & 3,23 & 0,80 & & & \\
\hline & $\begin{array}{l}\text { teknikeri } \\
\mathrm{H}-\end{array}$ & & & & & & \\
\hline & $\begin{array}{l}\text { Radyoloji } \\
\text { teknikeri }\end{array}$ & 34 & 2,87 & 0,75 & & & \\
\hline & $\begin{array}{l}\text { I-Anestezi } \\
\text { teknikeri }\end{array}$ & 19 & 3,38 & 0,89 & & & \\
\hline & $\begin{array}{l}\text { İ-Diğer } \\
\text { sağlik } \\
\text { personeli }\end{array}$ & 22 & 3,07 & 0,70 & & & \\
\hline \multirow{11}{*}{$\begin{array}{l}\text { İçsel } \\
\text { doyum }\end{array}$} & A-Hemşire & 321 & 3,23 & 0,79 & & & \multirow{11}{*}{$\begin{array}{l}\text { A-B } \\
\text { B-D } \\
\text { B-E } \\
\text { B-H }\end{array}$} \\
\hline & B-Hekim & 54 & 3,79 & 0,75 & & & \\
\hline & $\begin{array}{l}\text { C-Sağlık } \\
\text { memuru }\end{array}$ & 40 & 3,31 & 0,85 & & & \\
\hline & D-Ebe & 47 & 2,96 & 0,82 & & & \\
\hline & $\begin{array}{l}\text { E-Tibbi } \\
\text { sekreter }\end{array}$ & 52 & 3,22 & 0,66 & & & \\
\hline & F-Laborant & 30 & 3,39 & 0,66 & & & \\
\hline & $\begin{array}{l}\text { G-Acil tıp } \\
\text { teknikeri }\end{array}$ & 64 & 3,39 & 0,86 & 35,737 & 0,000 & \\
\hline & $\mathrm{H}-$ & & & & & & \\
\hline & $\begin{array}{l}\text { Radyoloji } \\
\text { teknikeri }\end{array}$ & 34 & 2,92 & 0,94 & & & \\
\hline & $\begin{array}{l}\text { I-Anestezi } \\
\text { teknikeri }\end{array}$ & 19 & 3,43 & 0,96 & & & \\
\hline & $\begin{array}{l}\text { İ-Diğer } \\
\text { sağlik } \\
\text { personeli }\end{array}$ & 22 & 3,28 & 0,79 & & & \\
\hline \multirow{6}{*}{$\begin{array}{l}\text { Dişsal } \\
\text { doyum }\end{array}$} & A-Hemşire & 321 & 3,11 & 0,81 & \multirow{6}{*}{17,334} & \multirow{6}{*}{0,051} & \\
\hline & B-Hekim & 54 & 3,24 & 0,87 & & & \\
\hline & $\begin{array}{l}\text { C-Sağlik } \\
\text { memuru }\end{array}$ & 40 & 3,17 & 0,84 & & & \\
\hline & D-Ebe & 47 & 2,81 & 0,92 & & & \\
\hline & $\begin{array}{l}\text { E-T1bbi } \\
\text { sekreter }\end{array}$ & 52 & 2,91 & 0,86 & & & \\
\hline & F-Laborant & 30 & 3,02 & 0,84 & & & \\
\hline
\end{tabular}




\begin{tabular}{lccc}
$\begin{array}{l}\text { G-Acil tıp } \\
\text { teknikeri }\end{array}$ & 64 & 3,00 & 0,91 \\
$\begin{array}{l}\text { H- } \\
\text { Radyoloji } \\
\text { teknikeri }\end{array}$ & 34 & 2,80 & 0,83 \\
$\begin{array}{l}\text { I-Anestezi } \\
\text { teknikeri }\end{array}$ & 19 & 3,32 & 0,99 \\
$\begin{array}{l}\text { I-Diğer } \\
\text { sağlik } \\
\text { personeli }\end{array}$ & 22 & 2,75 & 0,89 \\
\hline
\end{tabular}

Araştırmaya katılan sağlık personellerinin, meslek gruplarına göre iş doyumu puan ortalamaları arasında anlamlı bir fark olup olmadı̆̆ını incelemek için, Kruskal Wallis analizi yapılmıştır. Yapılan analize sonuçlar Tablo 4'te gösterilmiştir. Sağlık çalışanlarının, meslekler arasındaki iş doyumu puan ortalamaları arasındaki farkın istatistiksel olarak anlamlı olduğu tespit edilmiştir $(\mathrm{p}<0,05)$.Yapılan Post Hoc Tamhane analizi sonucuna göre, hekimlerin iş doyumu puan ortalamalarının $(3,57 \pm 0,70)$, hemşire, ebe, tıbbi sekreter ve radyoloji teknikerlerinin iş doyumu puan ortalamalarından yüksek olduğu ve aradaki farkın istatistiksel açıdan anlamlı olduğu tespit edilmiştir $(\mathrm{p}<0,05)$. Sağlık çalışanlarının, meslek gruplarına göre içsel doyum puan ortalamaları arasındaki farkın istatistiksel yönden anlamlı olduğu tespit edilmiştir $(\mathrm{p}<0,05)$. Yapılan Post HocTamhane's testi sonucuna göre, hekimlerin içsel doyum puan ortalamalarının $(3,79 \pm 0,75)$, hemşire, ebe, tıbbi sekreter ve radyoloji teknikerlerinin içsel doyum puan ortalamalarından yüksek olduğu ve aradaki farkın istatistiksel açıdan anlamlı olduğu saptanmıştır $(\mathrm{p}<0,05)$. Araştırmaya katılan sağlık çalışanlarının, meslek gruplarına göre dışsal doyum puan ortalamaları arasında istatistiksel yönden anlamlı bir fark olmadığı tespit edilmiştir ( $\mathrm{p}>0,05)$.

\subsection{Araştırma Hipotezlerine İlişsin Bulgular}

Hipotezlerde yer alan değişkenler arasındaki ilişkiyi ortaya koymak için Pearson Korelasyon analizi uygulanmıştır. Paternalist liderlik ve iş doyumu arasındaki ilişkiyi ortaya koymak için yapılan korelasyon analizi bulguları Tablo 5'te verilmiştir.

Tablo 5. Paternalist Liderlik ile İş Doyumu ve Örgütsel Adalet Arasındaki Korelasyon Analizi Bulguları. 


\begin{tabular}{lccc}
\hline & \multicolumn{3}{c}{ Paternalist Liderlik Ölçeği } \\
\cline { 2 - 4 } & $\mathrm{p}$ & $\mathrm{r}$ & $\mathrm{n}$ \\
\hline İçsel Doyum & 0,000 & 0,438 & 683 \\
Dişsal Doyum & 0,000 & 0,498 & 683 \\
Genel İş Doyumu & 0,000 & 0,530 & 683 \\
\hline
\end{tabular}

Paternalist liderlik ile genel iş doyumu arasında yüksek düzeyde $(\mathrm{p}<0,01)$, pozitif yönlü istatistiksel açıdan anlamlı bir ilişki olduğu saptanmıştır. Paternalist liderlik ile içsel doyum arasında yüksek düzeyde $(\mathrm{p}<0,01)$, pozitif yönde istatistiksel açıdan anlamlı bir ilişki olduğu saptanmıştır. Paternalist liderlik ile dışsal doyum arasında yüksek düzeyde $(\mathrm{p}<0,01)$, pozitif yönde istatistiksel açıdan anlamlı bir ilişki olduğu saptanmıştır.

Tablo 6' da, paternalist liderliğin, iş doyumu üzerindeki etkisine yönelik basit doğrusal regresyon analizi bulguları verilmiştir. Basit doğrusal regresyon analizi yapılırken, paternalist liderlik bağımsız değişken olarak belirlenirken, iş doyumu, içsel doyum, dışsal doyum, bağımlı değişkenler olarak belirlenmiştir.

Tablo 6. Paternalist Liderliğin, İş Doyumu ve Örgütsel Adalet Üzerindeki Yönelik Basit Doğrusal Regresyon Analizi Bulguları

\begin{tabular}{lllllllll}
\hline & \multicolumn{6}{c}{ Bağımsı Değişken: Paternalist Liderlik Ölçeği } \\
\hline $\begin{array}{l}\text { Bağı̆mlı } \\
\text { Değişkenler }\end{array}$ & $\mathrm{R}^{2}$ & $\mathrm{~F}$ & $\begin{array}{l}\text { Sabit } \\
\text { Katsayı }\end{array}$ & $\begin{array}{l}\text { Standart } \\
\text { hata }\end{array}$ & $\begin{array}{l}\text { Beta } \\
(\beta)\end{array}$ & $\mathrm{t}$ & $\mathrm{p}$ \\
\hline $\begin{array}{l}\text { İş Doyumu } \\
\text { Dışsal }\end{array}$ & 0,281 & 266,396 & 1,714 & 0,094 & 0,530 & 16,322 & 0,000 \\
$\begin{array}{l}\text { Doyum } \\
\text { İçsel } \\
\text { Doyumu }\end{array}$ & 0,248 & 224,156 & 1,422 & 0,113 & 0,498 & 14,972 & 0,000 \\
\hline
\end{tabular}

Paternalist liderliğin, iş doyumu üzerinde anlamlı ve yüksek düzeyde pozitif yönlü bir etkisi olduğu saptanmıştır $(\beta=530, \quad t=16,322$, $\mathrm{p}<0,01)$.Paternalist liderliğin, dışsal doyum üzerine yüksek düzeyde ve pozitif 
yönlü anlamlı bir etkisi olduğu saptanmıştır $(\beta=0,498, \quad t=14,972$, $\mathrm{p}<0,01)$.Paternalist liderliğin, içsel doyum üzerine yüksek düzeyde ve pozitif yönlü anlamlı bir etkisi olduğu belirlenmiştir $(\beta=0,438, \mathrm{t}=12,700, \mathrm{p}<0,01)$.

$\mathrm{H}_{1}$ : Paternalist liderlik davranışı ile genel iş doyumu arasında istatistiksel açıdan anlamlı bir ilişki vardır.

Yapılan korelasyon analizi sonucuna göre, paternalist liderlik ile genel iş doyumu arasında yüksek düzeyde, pozitif yönde istatistiksel açıdan anlamlı bir ilişki olduğu saptanmıştır( $(\mathrm{p}<0,01 ; \mathrm{r}=0,530)$. Yapılan basit doğrusal regresyon analizi sonucuna göre ise Paternalist liderliğin, genel iş doyumu üzerinde anlamlı ve yüksek düzeyde pozitif yönlü bir etkisi olduğu tespit edilmiştir $(\beta=530, t=16,322, p<0,01)$. Elde edilen sonuca göre $H_{1}$ hipotezi kabul edilmiştir.

$\mathrm{H}_{2}$ : Paternalist liderlik davranışı ile içsel doyum arasında istatistiksel açıdan anlamlı bir ilişki vardır.

Yapılan korelasyon analizi sonucuna göre, paternalist liderlik ile içsel doyum arasında yüksek düzeyde pozitif yönde istatistiksel açıdan anlamlı bir ilişki olduğu saptanmıştır ( $<<0,01 ; r=0,438)$.Yapılan basit doğrusal regresyon analizi sonucunda, Paternalist liderliğin, içsel doyum üzerinde yüksek düzeyde ve pozitif yönde anlamlı bir etkisi olduğu saptanmıştır ( $\beta=0,438$, $\mathrm{t}=12,700, \mathrm{p}<0,01$ ). Elde edilen sonuca göre $\mathrm{H}_{2}$ hipotezi kabul edilmiştir.

$\mathrm{H}_{3}$ : Paternalist liderlik davranışı ile dışsal doyum arasında istatistiksel açıdan anlamlı bir ilişki vardır.

Yapılan regresyon analizine göre, paternalist liderlik ile dışsal doyum arasında yüksek düzeyde pozitif yönde istatistiksel açıdan anlamlı bir ilişki olduğu saptanmıştır $(\mathrm{p}<0,01 ; \mathrm{r}=0,498)$. Yapılan basit doğrusal regresyon analizi sonucunda, paternalist liderliğin, dışsal doyum üzerinde yüksek düzeyde ve pozitif yönde anlamlı bir etkisi olduğu bulunmuştur ( $\beta=0,498$, $\mathrm{t}=14,972, \mathrm{p}<0,01)$. Bu sonuçlara göre, $\mathrm{H}_{3}$ hipotezi kabul edilmiştir.

\section{TARTIŞMA}

$\mathrm{Bu}$ çalışma, sağlık yöneticilerinin göstermiş olduğu paternalist liderlik davranışının, çalışanların iş doyumu üzerine etkisi olup olmadığını ortaya koymak amacı ile gerçekleştirilmiştir. 
$\mathrm{Bu}$ araştırmada, kamu hastanelerinde çalışanların paternalist liderlik ölçeği puan ortalaması $3,18 \pm 0,85$ olduğu ve özel hastanelerde çalışanların

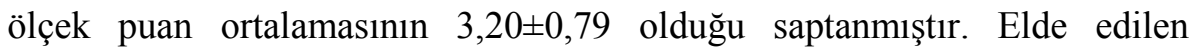
ortalamaya göre, yöneticilerin orta düzeyde paternalist liderlik davranışı gösterdiği saptanmıştır.

Bizim yaptığımız araştırmaya benzer şekilde, Türkiye'de farklı sektörlerde yapılan bazı araştırmalarda da benzer sonuçlar tespit edilmiştir. Pellegrini ve Scandura (2006), İstanbul ve Gebze'de bulunan üretim, iletişim, adalet ve finans sektörlerinde faaliyet gösteren beş farklı işletmede 185 kişinin katılımının sağlandığı araştırmada; paternalist liderlik puan ortalamasını $3,46 \pm 1,14$ olarak tespit etmiştir (Pellegrini ve Scandura 2006, s.271). Yaman (2011) Bursa ilinde 310 özel hastane çalışanları üzerinde yaptığ çalışmada paternalist liderlik ölçeği puan ortalamasını 3,55 $\pm 0,47$ olarak bulmuştur (Ortalama>3,00). Cerit (2013) paternalistik liderlik ile sınıf öğretmenlerine yönelik yıldırma davranışları arasındaki ilişkiyi ilişkiyi incelemek için Bolu ilindeki okullarda çalışan 283 öğretmen üzerinde yaptığı çalışmada paternalist

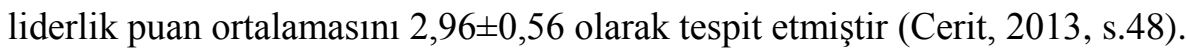

$\mathrm{Bu}$ çalışmada sağlık çalışanlarının, cinsiyete göre paternalist liderlik puan ortalamaları arasındaki farkın istatistiksel açıdan anlamlı olmadığı bulunmuştur ( $p>0,05)$. Benzer şekilde Yaman (2011) tarafindan yapılan çalışmada paternalist liderliğin, cinsiyete göre değişmediği tespit edilmiştir ( Yaman, 2011, s.110).

Sağlık çalışanlarının eğitim durumlarına göre paternalist liderlik puan ortalamaları arasındaki farkın istatistiksel açıdan anlamlı olmadığı saptanmıştır ( $p>0,05)$. Yapılan bazı çalışmalarda farklı sonuçlar elde edildiği görülmektedir. Yaman (2011) tarafından yapılan çalışmada eğitim seviyesi arttıkça paternalist liderlik puan ortalamasının azaldığı sonucunu elde etmiştir. Yardımcı (2010) bankacılık sektöründe 214 katılımcı üzerinde yaptığı araştırmada, eğitim düzeyi ile paternalist liderlik puan ortalamaları arasında anlamlı bir fark olduğunu tespit etmiştir. Buna göre eğitim düzeyi Lise/Önlisans olanların paternalist liderlik puan ortalamasının, eğitim düzeyi üniversite ve yüksek lisans olanların puan ortalamalarından anlamlı olarak yüksek olduğu sonucuna varmıştır (Yardımc1, 2014, s.72). 
Katılımcıların eğitim durumlarına göre iş doyumu puan ortalamaları arasındaki farkın istatistiksel açıdan anlamlı olduğu saptanmıştır $(p<0,05)$. Yapılan Post Hoc Tukey testi sonucunda, lisansüstü eğitim mezunlarının iş doyumu puan ortalarının $(3,40 \pm 0,70)$, üniversite mezunlarının iş doyumu puan ortalarından $(3,17 \pm 0,69)$ yüksek olduğu saptanmıştır. Sağlık çalışanlarının eğitim durumlarına göre içsel doyum puan ortalamaları arasındaki farkın istatistiksel açıdan anlamlı olduğu saptanmıştır $(\mathrm{p}<0,05)$. Yapılan Post Hoc Tukey testi sonucuna göre, lisansüstü eğitim mezunlarının içsel doyum puan ortalarının $(3,57 \pm 0,79)$, üniversite mezunlarının içsel doyumu puan ortalarından $(3,24 \pm 0,80)$ ve lise mezunlarının içsel doyumu puan ortalarından $(3,26 \pm 0,84)$ yüksek olduğu saptanmıştır. Çağan (2014), Malatya ilinde bulunan aile sağlığı merkezleri ve toplum sağlı̆̆1 merkezlerin de görev yapan sağlık çalışanlarının iş doyumu, tükenmişlik ve anksiyete düzeylerini incelemek için yaptığı çalışmada, eğitim düzeyi açısından gruplar arasında genel iş doyumu, içsel ve dışsal iş doyumu açısından bir fark olmadığını saptamıştır (Çağan, 2014, s.39). Gürvardar (2014), Ankara ilinde bulunan kamu ve özel hastanelerde vardiya sistemi ile çalışmanın, hemşirelerin çalışmadan duyulan memnuniyet düzeyine ve iş doyumuna etkisini belirlemek değerlendirmek için yaptığı çalışmada, eğitim durumuna göre hemşirelerin iş doyum düzeyleri arasında istatistiksel olarak anlamlı fark olmadığı sonucunu elde etmiş̧tir (Gürvardar, 2014, s.76). Leider ve arkadaşları (2016), Amerika Birleşik Devletleri'nde sağlık çalışanları üzerinde yaptı̆̆ bir araştırmada, sağlık çalışanlarının eğitim düzeyi ile iş doyumu arasında istatistiksel açıdan anlamlı bir fark olmadığı belirlenmiştir (Leider ve vd., 2016, s.1785).Literatürde farklı sonuçlar elde edildiği görülmektedir. Erşan ve vd.,(2013), Sivas ilinde bir kamu hastanesinde sağlık çalışanları üzerinde yaptığı araştırmada, lisansüstü eğitim mezunlarının iş doyumlarının, önlisans ve lisans mezunu olanların iş doyumlarından daha yüksek olduğunu saptamıştır (Erşan ve vd., 2013, s.119). Literatür incelendiğinde eğitim durumu ve iş doyumu arasındaki ilişki ile ilgili farklı sonuçlar elde edildiği görülmektedir. $\mathrm{Bu}$ farklı sonuçların nedeni, kişinin eğitim durumuna uygun bir pozisyonda çalışıp çalışmadığı veya eğitim durumuna uygun yetki ve sorumlulukların verilip verilmediği ile ilgili olabilir. 
Katılımcıların çalışma vardiyası durumlarına göre içsel doyum puan ortalamaları arasındaki farkın istatistiksel yönden anlamlı olduğu tespit edilmiştir $(p<0,05)$. Yapılan Post Hoc Tamhane testi sonucuna göre, gündüz vardiyasında çalışanların içsel doyum puan ortalarının $(3,32 \pm 0,84)$, gece vardiyasında çalışanların içsel doyum puan ortalarından $(2,57 \pm 0,58)$ yüksek olduğu saptanmıştır. Ayrıca hem gece hem de gündüz vardiyasında çalışanların içsel doyum puan ortalarının $(3,27 \pm 0,80)$, gece vardiyasında çalışanların iş doyumu puan ortalarından $(2,57 \pm 0,58)$ yüksek olduğu tespit edilmiştir. Gürvardar (2014), Ankara ilinde bulunan kamu ve özel hastanelerde vardiya sistemi ile çalışmanın, hemşirelerin çalışmadan duyulan memnuniyet düzeyine ve iş doyumuna etkisini belirlemek için yaptığ çalışmada, ayda bir kez vardiyalı çalışanların iş doyumu puanlarının $(3,32 \pm 0,54)$, sürekli vardiyalı çalışanların puan ortalamalarından yüksek olduğu $(3,25 \pm 0,69)$ ve bu farkın istatistiksel açıdan anlamlı olduğu tespit edilmiştir (Gürvardar, 2014, s.79). Her iki çalışmada da yalnız gece vardiyasında çalışanların, diğer vardiyalarda çalışanlara göre iş doyumlarının düşük olduğu görülmüsstür.

Sağlık çalışanlarının, meslekler arasındaki iş doyumu puan ortalamaları arasındaki farkın istatistiksel olarak anlamlı olduğu tespit edilmiştir $(\mathrm{p}<0,05)$. Yapılan Post Hoc Tamhane analizi sonucuna göre, hekimlerin iş doyumu puan ortalamalarının $(3,57 \pm 0,70)$, hemşire, ebe, tıbbi sekreter ve radyoloji teknikerlerinin iş doyumu puan ortalamalarından yüksek olduğu ve aradaki farkın istatistiksel açıdan anlamlı olduğu tespit edilmiştir $(p<0,05)$. Erşan ve vd.,(2013), Sivas ilinde bir kamu hastanesinde yaptığı araştırmada, hekimlerin iş doyumu puan ortalamalarının, diğer çalışanlardan yüksek olduğu ve bu farkın istatistiksel açıdan anlamlı olduğu sonucuna varmıştır (Erşan ve vd., 2013, s.118). Mertoğlu (2013), Gülhane Askeri Tıp Akademisi Eğitim ve Araştırma Hastanesi'nde çalışan asistan hekimler, hemşireler ve diğer sağlık personeli üzerinde yaptığı bir araştırmada, hekimlerin genel iş doyumu düzeyinin hemşire ve diğer sağlık personelinin iş doyumu düzeyinden daha yüksek olduğu sonucunu bulmuştur (Mertoğlu, 2013, s.92). Kaya ve Oğuzöncül (2016), Elazığ ilinde 282 sağlık çalışanı üzerinde yaptığı çalışmada, hekimlerin ve hekim dışı sağlık personellerinin iş doyumu puan ortalamalarının, hizmetli ve diğer personellerin iş doyumu puanlarından 
yüksek olduğunu tespit etmiştir (Kaya ve Oğuzöncül, 2016, s.251). Suarez ve arkadaşlarının (2016) İspanya'da, hekim, hemşire ve idari personel çalışanları üzerinde yaptı̆̆ bir araştırmada, idari personellerin iş doyumlarının, hekim ve hemşirelerin iş doyumlarından yüksek olduğunu saptamıştır (Suarez ve vd., 2016, s.33).Genel olarak Türkiye'de yapılan çalışmalarda hekimlerin iş doyumlarının daha yüksek olduğu ve bizim çalışmamı ile uyumlu olduğu görülmekte iken yurt dışında yapılan bir çalışmada hekimlerin iş doyumlarının diğer meslek gruplarına göre daha düşük olduğu görülmektedir. Bu durumun nedeni olarak, Türkiye'de çalışan hekimlerin çalışma koşullarının, İspanya'da çalışan hekimlerin çalışma koşullarından daha iyi olması gösterilebilir.

$\mathrm{Bu}$ araştırmada, paternalist liderlik davranışı ile genel iş doyumu, içsel doyum ve dışsal doyum arasında istatistiksel açıdan anlamlı bir ilişki olduğu saptanmıştır. Elde edilen sonuca göre $\mathrm{H}_{1}, \mathrm{H}_{2}$ ve $\mathrm{H}_{3}$ hipotezleri kabul edilmiştir. Farklı sektörlerde yapılan araştırmalarda da benzer sonuçlar elde edildiği görülmektedir. Pellegrini ve Scandura(2006), İstanbul ve Gebze'de bulunan üretim, iletişim, yasa ve finans sektörlerinde faaliyet gösteren beş farklı işletmede 185 kişinin katılımının sağlandığı araştırmada; paternalist liderlik davranışının, iş tatmini ve lider-üye etkileşimi ile pozitif ilişkili olduğu sonucuna ulaşmışlardır (Pellegrini ve Scandura 2006, s.272). Pellegrini ve vd., (2010) Hindistan'da çalışan 207 kişi ve Amerika'da aynı özellikleri sahip 215 kişi üzerinde bir araştırma yapmıştır. Araştırma sonucuna göre, paternalist liderliğin Amerika'ya göre Hindistan'da daha yüksek olduğunu ve paternalist liderliğin Hindistan'da iş doyumu üzerinde önemli bir pozitif etkiye sahip olduğu tespit edilirken, Amerika'da çalışanlar üzerinde böyle bir etkinin olmadığı tespit edilmiştir. Chou (2012), Güney Tayvan Bilimsel Araştırmalar Parkı'nda 259 çalışan üzerinde yaptığı çalışmada, paternalist liderliğin alt boyutları olan, yardımsever liderliğin ve ahlaki liderliğin iş doyumu üzerine pozitif yönlü etkisi olduğunu fakat paternalist liderliğin bir diğer alt boyutu olan otoriter liderliğin içsel doyum üzerine negatif etkisi olduğunu saptamıştır (Chou, 2012, s.75-76). 


\section{SONUÇ}

Yöneticilerin, yönetimin fonksiyonlarını yerine getirmek için kullandıkları en önemli kaynaklardan biri de insan kaynaklarıdır. Günümüzde yöneticilerin, çalışanlarını yönetme konusunda karşılaştıkları problemlerden biride çalışanların iş doyumunu sağlamaktır.

Gece vardiyasında çalışanların iş doyumlarının, gece vardiyasında çalışmayanlara göre düşük olduğu görülmektedir. Düzenli bir dinlenme saati olmayan ve neredeyse mesailerinin tamamını ayakta çalışarak geçiren sağlık çalışanlarının, daha az gece mesai yapabilmesi için, personel eksikliğinin giderilmesi, nöbet dağılımlarının adil yapılması, haftalık 40 saat olan zorunlu çalışma süresinin makul seviyelere çekilmesi, gece çalışanlara daha fazla ücret verilmesi, daha fazla izin süresi verilmesi gibi tedbirle bu sorun ekarte edilebilir.

Hekimlerin iş doyumlarının diğer sağlık çalışanlarından daha yüksek olduğu tespit edilmiştir ve bu sonuç Türkiye'de yapılan çalışmaların sonuçları ile benzerlik göstermektedir. Bunun nedeni toplumumuzda hekimlik mesleğinin saygın bir yeri olması, diğer çalışanlara göre daha yüksek ücret alması, diğer çalışanlara göre bağımsız çalışma rollerinin daha fazla olması gibi nedenler sayılabilir.

Paternalist liderlik davranışının, iş doyumu ve iş doyumunun alt boyutları olan içsel doyum ve dışsal doyum üzerinde olumlu bir etkisi olduğu saptanmıştır. Sağlık yöneticilerinin,paternalist liderlik davranışı gösterdiği oranda çalışanlarında iş doyumunun artması beklenmektedir.Yöneticilerin, çalışanlarını yakından tanıması, işyerinde aile atmosferi oluşturması, çalışanlarını bir aile büyüğü gibi koruyup kollaması, çalışanlarının düğün ve cenaze gibi törenlerine katılması, doğum günü gibi özel günlerini kutlaması gibi davranışlar göstererek çalışanların iş doyumunu arttırabilir.

\section{KAYNAKLAR}

Anwar, H. (2013). Impact of paternalisticleadership on employeesoutcome a study on thebankingsector of Pakistan. IOSR Journal Of Business And Management, 7(6), 109-115.

Aycan, Z. (2006). Paternalism: Towards conceptual refinement and operationalization. U. Kim, K. Yang ve KK Hwang, (Eds.), 
Indigenous and cultural psychology: Understanding People in Context içinde (pp.445-466). New York: Springer US

Aycan, Z., Kanungo, R., Mendonca, M., Yu, K., Deller, J., Stahl, G., ve Kurshid, A. (2000). Impact of culture on human resource management practices: A 10-country comparison. Applied Psychology, 49(1), 192221.

Aziri, B. (2011). Job satisfaction: A literature review. Management Research and Practice, 3(4), 77-86.

Bakker, A.B., ve Demerouti, E. (2007). Thejobdemands-resources model: State of the Art. Journal of ManagerialPsychology, 22(3), 309-328.

Bass, B. (1960). Leadership, Psychology and Organizational Behavior. New York: Harper and Row.

Burns, James, MacGregor. (1979). Two excepts from leadership. Educational Leadership, 36(6), 380-383.

Cerit, Y. (2013). Paternalist liderlik ile öğretmenlere yönelik yıldırma davranışları arasındaki ilişki. Kuram ve Uygulamada Eğitim Bilimleri Dergisi, 13(2), 839-851.

Chou, H. J. (2012). Effects of paternalisticleadership on jobsatisfactionregulatoryfocus as themediator. International Journal of OrganizationalInnovation, 4(4), 62.

Çağan Ö. (2014). Malatya ilindeki Aile Sağllğ ve Toplum Să̆lı̆̆ Merkezlerinde Görev Yapan Sağllk Çalışanlarının İs Doyumu, Tükenmişlik ve Anksiyete Düzeyleri. (Yayımlanmamış doktora tezi). Erciyes Üniversitesi, Sağlık Bilimleri Enstitüsü, Kayseri.

Erşan, E. E., Yıldırım, G., Doğan, O., ve Doğan, S. (2013). Sağl1k çalışanlarının iş doyumu ve algılanan iş stresi ile aralarındaki ilişkinin incelenmesi. Anadolu Psikiyatri Dergisi, 14, 115-121.

Gürvardar, Y. (2014). Hastanelerde hemşirelerin shift (vardiya) yöntemi ile çalışmasinın iş doyumuna etkisini belirlemeye yönelik bir alan çalışması. (Yayımlanmamış yüksek lisans tezi) Gazi Üniversitesi, Sosyal Bilimler Enstitüsü, Yüksek Lisans Tezi, Ankara.

Izvercian, M., Potra, S., Ivascu, L. (2016). Job satisfaction variables: A grounded theory approach. Procedia-Social and Behavioral Sciences, 221, 86-94.

Jackson, T. (2016). Paternalisticleadership: Themissing link in cross-cultural leadership studies? International Journal of Cross Cultural Management, 16(1), 3-7.

Kaya, F., ve Oğuzöncül, A. F. (2016). Birinci Basamak Sağlık Çalışanlarında İş Doyumu ve Etkileyen Faktörler. Dicle Medical Journal/Dicle Tip Dergisi, 43(2), 248-255. 
Keklik, B. (2012). Sağlik hizmetlerinde benimsenen liderlik tiplerinin belirlenmesi: Özel bir hastane örneği. Afyon Kocatepe Üniversitesi IIBF Dergisi, 14(1), 73-93.

Kibbe, M. R. (2015). Leadership in Surgery. In: Kibbe M. R., ve Chen, H. eds. Switzerland: Springer International Publishing.

Kejanlıoğlu, B. (2005). Medya Çalışmalarında Kamusal Alan Kavramı. Meral Özbek (Ed.), Kamusal Alan içinde (s. 689-713). İstanbul: Hil.

Koçel, T. (2011). İşletme yöneticiliği. 13. Baskı, İstanbul: Beta Basım.

Leider, J. P., Harper, E., Shon, J. W., Sellers, K., ve Castrucci, B. C. (2016). Job satisfaction and expected turnover among federal, state, and local public health practitioners. American Journal of Public Health, 106(10), 1782-1788.

Mertoğlu, S. (2013). Gülhane Askeri Tıp Fakültesi Eğitim Hastanesi'nde çalışan sağllk personelinin tükenmişlik ve iş doyumu düzeylerini etkileyen faktörlerin incelenmesi. (Yayımlanmamış yüksek lisans tezi) Hacettepe Üniversitesi, Sosyal Bilimler Enstitüsü, Ankara.

Mustafa, G., ve Lines, R. (2012). Paternalism as a predictor of leadership behaviors: A bi-level analysis. Eurasian Business Review, 2(1), 63-92.

Oran, N.B. (1989). A study on jobsatisfaction of a group academical staff in Marmara University. (Yayımlanmamış yüksek lisans tezi) Marmara Üniversitesi, Sosyal Bilimler Enstitüsü, İstanbul.

Özkalp, E. (2013). Duygular, tutumlar ve iş tatmini. Kırel, Ç. A., ve Ağlargöz, O. (Eds.), Örgütsel adalet içind (pp. 71-80). Eskişehir: Anadolu Üniversitesi Yayını.

Pellegrini, E. K., ve Scandura, T. A. (2006). Leader-member exchange (LMX), paternalism, and delegation in the Turkish business culture: An empirical investigation. Journal of International Business Studies, 37(2), 264-279.

Pellegrini, E. K., ve Scandura, T. A. (2008). Paternalistic leadership: A review and agenda for future research. Journal of management, 34(3), 566593.

Pellegrini, E. K., Scandura, T. A., ve Jayaraman, V. (2010). Cross-cultural generalizability of paternalistic leadership: An expansion of leadermember exchange theory. Group ve Organization Management, 35(4), 391-420.

Salminen-Karlsson, M. (2015). Expatriate paternalistic leadership and gender relations in small European software firms in India. Culture and Organization, 21(5), 409-426.

Stogdill, R. M. (1950). Leadership, membership and organization. Psychological Bulletin, 47(1), 1-14. 
Suarez, M., Asenjo, M., Sanchez, M. (2017). Job satisfaction among emergency department staff, Australasian Emergency Nursing Journal, 20(1); 31-36.

Sur, H., ve Palteki, T. Hastane Yönetimi. İstanbul: 1. Bask1, Nobel Tıp Kitabevi.

Tanrıverdi, H., ve Paşaoğlu, S. (2014). Dönüşümcü liderlik, örgütsel adalet ve iş tatmini arasındaki ilişkileri belirlemeye yönelik okul öncesi öğretmenleri üzerinde bir araştırma. Elektronik Sosyal Bilimler Dergisi, 13(50), 274-293.

Tengilimoğlu, D. (2005). Hizmet işletmelerinde liderlik davranışları ile iş doyumu arasındaki ilişkinin belirlenmesine yönelik bir araştırma. Ticaret ve Turizm Eğitim Fakültesi Dergisi, 11(5), 21-27.

Türesin, H. (2012). Örgüt çalışanlarının paternalistik liderlik algıları, ögrenilmiş güçlülük düzeyleri, iş tatmin düzeyleri ve işten ayrılma niyetleri arasındaki ilişkilerin incelenmesi. (Yayımlanmamış yüksek lisans tezi). Celal Bayar Üniversitesi, Sosyal Bilimler Enstitüsü, Manisa.

Türesin, Tetik, H., ve Köse, S. (2015). Örgüt çalışanlarının paternalistik liderlik algıları ve öğrenilmiş güçlülük düzeyleri arasındaki ilişkilerin incelenmesi. Uluslararası Yönetim İktisat ve İşletme Dergisi, 11(26), 29-56.

Yaman, T. (2011). Yöneticilerin paternalist (babacan) lider davranışlarının çalışanların örgütsel özdeşleşmelerine, iş performanslarına ve işten ayrllma niyetlerine etkisi: özel sektörde uygulama. (Yayımlanmamış yüksek lisans tezi). Kara Harp Okulu, Ankara.

Yardımc1, C. (2010). Paternalistik liderlik davranışlarının iş tatmini üzerindeki etkisi: Bankacıllk sektörü üzerinde bir uygulama. (Yayımlanmamış yüksek lisans tezi). Hacettepe Üniversitesi, Sosyal Bilimler Enstitüsü, Ankara.

Yeşiltaş, M. (2013). Paternalist liderliğin örgütsel vatandaşlık davranışları üzerindeki etkisinde dağıtım adaletinin aracılık rolü. Işletme Araştırmaları Dergisi, 5(4), 50-70. 